\title{
Present and future of allogeneic natural killer cell therapy
}

\author{
Okjae Lim ${ }^{1}$, Mi Young Jung ${ }^{1}$, Yu Kyeong Hwang ${ }^{2}$ and Eui-Cheol Shin ${ }^{3 *}$ \\ ${ }^{1}$ Virology and Immunology Team, MOGAM Biotechnology Institute, Yongin, South Korea, ${ }^{2}$ Cell Therapy Center, GreenCross \\ LabCell, Yongin, South Korea, ${ }^{3}$ Laboratory of Immunology and Infectious Diseases, Graduate School of Medical Science and \\ Engineering, KAIST, Daejeon, South Korea
}

Natural killer (NK) cells are innate lymphocytes that are capable of eliminating tumor cells and are therefore used for cancer therapy. Although many early investigators used autologous NK cells, including lymphokine-activated killer cells, the clinical efficacies were not satisfactory. Meanwhile, human leukocyte antigen (HLA)-haploidentical hematopoietic stem cell transplantation revealed the antitumor effect of allogeneic NK cells, and HLAhaploidentical, killer cell immunoglobulin-like receptor ligand-mismatched allogeneic NK cells are currently used for many protocols requiring NK cells. Moreover, allogeneic NK cells from non-HLA-related healthy donors have been recently used in cancer therapy. The use of allogeneic NK cells from non-HLA-related healthy donors allows the selection of donor NK cells with higher flexibility and to prepare expanded, cryopreserved NK cells for instant administration without delay for ex vivo expansion. In cancer therapy with allogeneic NK cells, optimal matching of donors and recipients is important to maximize the efficacy of the therapy. In this review, we summarize the present state of allogeneic NK cell therapy and its future directions.

Keywords: natural killer cells, allogeneic, cancer immunotherapy, adoptive cell therapy, non-HLA-related donor

\section{Introduction}

Cancer is a major threat for humans worldwide, with approximately 14 million new cases and 8.2 million cancer-related deaths in 2012 (1). Although most common cancer treatments include surgery, chemotherapy, and radiotherapy, unsatisfactory cure rates require new therapeutic approaches, especially for refractory cancers. For this purpose, cancer immunotherapies with various cytokines, antibodies, and immune cells have been clinically applied to patients to encourage their own immune system to help fight the cancer (2).

Adoptive cellular immunotherapies have employed several types of immune cells, including dendritic cells (DCs), cytotoxic T lymphocytes (CTLs), lymphokine-activated killer (LAK) cells, cytokine-induced killer (CIK) cells, and natural killer (NK) cells. Although there has been recent progress in DC therapy and CTL therapy, clinical applications are somewhat limited because cancer antigens must first be characterized and autologous cells must be used. By contrast, LAK cells, CIK cells, and NK cells have antigen-independent cytolytic activity against tumor cells. In particular, NK cells can be used from not only autologous sources but also allogeneic sources and, recently, allogeneic NK cells have been employed more often in cancer treatment. Whereas autologous NK cells from cancer patients may have functional defects (3), allogeneic NK cells from healthy donors have normal function and can be safely administered to cancer patients (4). Allogeneic NK cell therapy is particularly beneficial because it can enhance the anti-cancer efficacy of NK cells via donor-recipient incompatibility in terms of killer cell immunoglobulin-like receptors (KIRs) on donor NK cells and major histocompatibility complex (MHC) class I on recipient tissues. 


\section{Biology of NK Cells and Their Receptors}

Natural killer cells are innate lymphocytes that provide a first line of defense against viral infections and cancer (5). Human NK cells are recognized as $\mathrm{CD} 3{ }^{-} \mathrm{CD} 56^{+}$lymphocytes. They can be further subdivided into two subsets based on the surface expression level of CD56. The CD56 ${ }^{\mathrm{dim}}$ population with low-density expression of CD56 comprises approximately $90 \%$ of human blood NK cells and has a potent cytotoxic function, whereas the CD56 ${ }^{\text {bright }}$ population (approximately 10\% of blood NK cells) with highdensity expression of CD56 displays a potent cytokine producing capacity and has immunoregulatory functions (6). The CD56 $6^{\mathrm{dim}}$ NK cell subset also expresses high levels of the Fc receptor for IgG (FcyRIII, CD16), which allows them to mediate antibodydependent cellular cytotoxicity (ADCC) (7). NK cells comprise $5-15 \%$ of circulating lymphocytes and are also found in peripheral tissues, including the liver, peritoneal cavity, and placenta. Activated NK cells are capable of extravasation and infiltration into tissues that contain pathogens or malignant cells while resting NK cells circulate in the blood (8).

The NK cell activity is regulated by signals from activating and inhibitory receptors $(9,10)$. The activating signal is mediated by several NK receptors including NKG2D and natural cytotoxicity receptors (NCRs) (9-11). By contrast, NK cell activity is suppressed by inhibitory receptors, including KIRs, which bind to human leukocyte antigen (HLA) class I molecules on target cells $(9,10,12)$. NKG2A is also an important inhibitory receptor binding to non-classical HLA molecule, HLA-E (13). If target cells lose or downregulate HLA expression (14), the NK inhibitory signal is abrogated, allowing NK cells to become activated and kill malignant targets. However, NK cell function is impaired in cancer patients by various mechanisms, particularly in tumor microenvironment (15).

Although NK cell activity is determined by the summation of signals from activating and inhibitory receptors, the inhibitory signal through KIRs is a main regulator of NK cell function particularly in allogeneic settings. Inhibitory KIRs have long cytoplasmic tails containing two immunoreceptor tyrosinebased inhibition motifs (ITIMs). Each KIR has its cognate ligand and consists of two (KIR2DL) or three (KIR3DL) extracellular Ig-domains. KIR2DL1 and KIR2DL2/3 recognize group 2 HLA-C (called C2, Lys80) and group 1 HLA-C (called C1, Asn80), respectively. KIR3DL1 recognizes HLA-Bw4 (16). The KIR repertoire on human NK cells is randomly determined and independent of the number and allotype of HLA class I ligands (17).

\section{Therapeutic Efficacy of Allogeneic NK Cells}

\section{Role of Allogeneic NK Cells in Hematopoietic Stem Cell Transplantation}

The antitumor activity of allogeneic NK cells has been demonstrated in the setting of hematopoietic stem cell transplantation (HSCT). Allogeneic HSCT is an established curative treatment for hematologic malignancies. In allogeneic HSCT, donor T cells contribute to graft-versus-host disease (GVHD) and graft-versustumor (GVT) effects (18). In T cell-depleted HSCT, however, donor NK cells are the major effector cells responsible for controlling residual cancer cells before $\mathrm{T}$ cell reconstitution $(19,20)$.

Natural killer cells are the first lymphoid population to recover after allogeneic HSCT. In the first month of transplantation, reconstituted NK cells represent the predominant lymphoid cells and play a crucial role in controlling the host immune system. Allogeneic NK cells prevent viral infections and restrain residual cancer cells in the early phase of transplantation (21). Of note, the GVT activity of donor NK cells is significantly improved when KIRs of donor and HLA class I of the recipient are incompatible, and consequently when inhibitory signals are absent, as observed in HLA-haploidentical HSCT (22). Therefore, increased GVT activity of NK cells with KIR-HLA incompatibility is the underlying rationale for the development of allogeneic NK cell therapy.

\section{Allogeneic NK Cell-Based Immunotherapy}

Following the discovery of inhibitory KIRs and the understanding that they play a role in preventing NK cell killing of self MHC class I-expressing tumor cells, investigators began to research the possibility of using allogeneic donor NK cells instead of autologous NK cells for cancer therapy. Several groups have infused activated, expanded donor NK cells to patients early after allogeneic HSCT to provide antitumor effects (23). In Table 1, clinical trials with allogeneic NK cells as therapeutics are summarized.

Allogeneic NK cells can be delivered either in a setting of HSCT or a non-HSCT setting. HSCT is a curative platform for many patients with hematologic malignancies. For patients lacking an HLA-identical donor and for those with progressive disease, the use of HLA-haploidentical family donors is increasingly considered to be a suitable alternative. Therefore, in most clinical trials using allogeneic NK cells, autologous or haploidentical HSCT are followed by NK cell infusion as therapeutics to protect relapse and delay recurrence. Several groups have explored the use of allogeneic NK cells in treating relapses of hematologic malignancies following HLA-haploidentical HSCT in clinical trials, and GVHD did not develop when allogeneic haploidentical NK cells were used $(19,24)$. In these studies, tumor responses were observed in some patients and overall rates of relapse were reduced. Notably, infusion of allogeneic NK cells can cause cancer regression even without allogeneic HSCT. The patients received allogeneic NK cells without HSCT following non-myeloablative chemotherapy. The chemotherapy pre-conditioning delayed the rejection of the transferred cells, and in some cases, the allogeneic NK population even expanded before being ultimately rejected $(25,26)$.

In a non-transplantation setting, Miller and colleagues were the first to establish the safety and efficacy of adoptive cellular transfer of HLA-haploidentical NK cells in patients with advanced cancer (27). In this study, 19 acute myeloid leukemia (AML) patients were given haploidentical NK cell infusions together with IL-2 and 5 patients achieved complete remission. Allogeneic NK cells with KIR-HLA mismatches between patients and donors exhibited greater tumor-killing activity without causing GVHD. Based on the success observed in AML, a number of clinical trials are being carried out to determine the feasibility and efficacy of allogeneic NK cell infusion for cancer treatment. Many of 15 ongoing clinical trials are oriented to hematological malignancies including 
TABLE 1 | Selected clinical trials with expanded allogeneic NK cells.

\begin{tabular}{|c|c|c|c|c|c|c|}
\hline Diseases & Status & $\begin{array}{l}\text { Phase of } \\
\text { trials }\end{array}$ & Cell product & Combined therapy & Institute & $\begin{array}{l}\text { ClinicalTrials.gov } \\
\text { Identifier }\end{array}$ \\
\hline Hepatocellular carcinoma & Ongoing & Phase 2 & $\begin{array}{l}\text { Ex vivo-expanded NK } \\
\text { cells }\end{array}$ & None & $\begin{array}{l}\text { Samsung Medical Center, } \\
\text { Korea }\end{array}$ & NCT02008929 \\
\hline $\begin{array}{l}\text { Lymphoma and solid } \\
\text { tumors }\end{array}$ & Completed & Phase 1 & $\begin{array}{l}\text { Ex vivo-expanded NK } \\
\text { cells }\end{array}$ & None & $\begin{array}{l}\text { Seoul National University } \\
\text { Hospital, Korea }\end{array}$ & NCT01212341 \\
\hline High-risk solid tumors & Ongoing & Phase 2 & $\begin{array}{l}\text { Ex vivo-expanded NK } \\
\text { cells }\end{array}$ & $\begin{array}{l}\text { Haploidentical HSCT, } \\
\text { RIC, and IL-2 }\end{array}$ & $\begin{array}{l}\text { Samsung Medical Center, } \\
\text { Korea }\end{array}$ & NCT01807468 \\
\hline $\begin{array}{l}\text { Non-B lineage hematologic } \\
\text { malignancies and solid } \\
\text { tumors }\end{array}$ & Completed & Phase 1 & $\begin{array}{l}\text { Ex vivo-expanded } \\
\text { haploidentical NK cells }\end{array}$ & $\begin{array}{l}\text { Chemotherapy and } \\
\text { IL-2 }\end{array}$ & $\begin{array}{l}\text { St. Jude Children's Research } \\
\text { Hospital, USA }\end{array}$ & NCT00640796 \\
\hline Hematological malignancies & Ongoing & Phase 1 & IL-2-activated NK cells & $\begin{array}{l}\text { Haploidentical HSCT } \\
\text { and RIC }\end{array}$ & $\begin{array}{l}\text { Institut Paoli-Calmettes, } \\
\text { France }\end{array}$ & NCT01853358 \\
\hline Multiple myeloma & Ongoing & Phase $1 / 2$ & $\begin{array}{l}\text { Ex vivo-expanded } \\
\text { haploidentical NK cells }\end{array}$ & $\begin{array}{l}\text { Autologous HSCT } \\
\text { and chemotherapy }\end{array}$ & $\begin{array}{l}\text { University Hospital, Basel, } \\
\text { Switzerland }\end{array}$ & NCT01040026 \\
\hline $\begin{array}{l}\text { Leukemia and } \\
\text { myeloproliferative disease }\end{array}$ & Ongoing & Phase 1/2 & $\begin{array}{l}\text { Ex vivo-expanded NK } \\
\text { cells }\end{array}$ & $\begin{array}{l}\text { Haploidentical HSCT, } \\
\text { TBI, and } \\
\text { chemotherapy }\end{array}$ & $\begin{array}{l}\text { M.D. Anderson Cancer } \\
\text { Center, USA }\end{array}$ & NCT01904136 \\
\hline ALL & Ongoing & Phase 2 & $\begin{array}{l}\text { K562-mb15-41BBL } \\
\text { and IL-2-stimulated NK } \\
\text { cells }\end{array}$ & $\begin{array}{l}\text { Haploidentical HSCT } \\
\text { and chemotherapy }\end{array}$ & $\begin{array}{l}\text { National University Health } \\
\text { System, Singapore }\end{array}$ & NCT01974479 \\
\hline AML and ALL & Ongoing & Phase 1/2 & $\begin{array}{l}\text { Ex vivo-expanded NK } \\
\text { cells }\end{array}$ & Haploidentical HSCT & Asan Medical Center, Korea & NCT01795378 \\
\hline $\begin{array}{l}\text { Relapsed/refractory } \\
\text { pediatric acute leukemia }\end{array}$ & Ongoing & Phase 2 & $\begin{array}{l}\text { Activated and } \\
\text { expanded NK cells }\end{array}$ & $\begin{array}{l}\text { Haploidentical HSCT } \\
\text { and salvage } \\
\text { chemotherapy }\end{array}$ & $\begin{array}{l}\text { Hospital Universitario La Paz, } \\
\text { Spain }\end{array}$ & NCT02074657 \\
\hline $\begin{array}{l}\text { Myelodysplastic syndrome } \\
\text { and leukemia }\end{array}$ & Completed & Phase 1/2 & IL-2-activated NK cells & $\begin{array}{l}\text { Haploidentical HSCT, } \\
\text { chemotherapy, and } \\
\text { IL-2 }\end{array}$ & $\begin{array}{l}\text { M.D. Anderson Cancer } \\
\text { Center, USA }\end{array}$ & NCT00402558 \\
\hline Leukemia & Completed & Phase 2 & IL-2-activated NK cells & $\begin{array}{l}\text { Chemotherapy and } \\
\text { IL-2 }\end{array}$ & $\begin{array}{l}\text { Masonic Cancer Center, } \\
\text { University of Minnesota, USA }\end{array}$ & NCT00274846 \\
\hline $\begin{array}{l}\text { Relapsed/refractory } \\
\text { pediatric T cell leukemia and } \\
\text { lymphoma }\end{array}$ & Ongoing & Phase 1/2 & $\begin{array}{l}\text { Activated and } \\
\text { expanded NK cells }\end{array}$ & $\begin{array}{l}\text { Salvage } \\
\text { chemotherapy }\end{array}$ & $\begin{array}{l}\text { Hospital Infantil Universitario } \\
\text { Niño Jesús, Madrid, Spain }\end{array}$ & NCT01944982 \\
\hline Leukemia & Ongoing & Phase 1/2 & $\begin{array}{l}\text { mblL21-expanded } \\
\text { haploidentical NK cells }\end{array}$ & Chemotherapy & $\begin{array}{l}\text { M.D. Anderson Cancer } \\
\text { Center, USA }\end{array}$ & NCT01787474 \\
\hline $\begin{array}{l}\text { Acute leukemia and } \\
\text { myelodysplastic syndrome }\end{array}$ & Ongoing & Phase 1 & $\begin{array}{l}\text { K562-mb15-41BBL } \\
\text { and IL-2-stimulated NK } \\
\text { cells }\end{array}$ & $\begin{array}{l}\text { Immunosuppressive } \\
\text { therapy and IL-2 }\end{array}$ & $\begin{array}{l}\text { National University Hospital, } \\
\text { Singapore }\end{array}$ & NCT02123836 \\
\hline
\end{tabular}

HSCT, hematopoietic stem cell transplantation; RIC, reduced-intensity conditioning; ALL, acute lymphocytic leukemia; AML, acute myeloid leukemia; TBI, total body irradiation.

leukemia, multiple myeloma, and myelodysplastic/proliferative diseases. Additionally, clinical trials have shown that allogeneic NK cells play a therapeutic role in solid tumors $(26,28,29)$. The clinical efficacy of expanded allogeneic NK cells was investigated in patients with recurrent metastatic breast and ovarian cancers in combination with a $\mathrm{Hi}-\mathrm{Cy} / \mathrm{Flu}$ preparative chemotherapy regimen (29). Adoptive transfer of ex vivo-expanded allogeneic NK cells was safe and effective in patients with advanced non-small cell lung cancer (26). These findings provided proof of concept that allogeneic NK cells could be effective not only in hematologic malignancy patients but also in solid tumor patients. Clinical trials are currently carried out in hepatocellular carcinoma and neuroblastoma (NCT02008929, NCT01807468).

Adoptive transfer of allogeneic NK cells that come from a totally unrelated donor has also been demonstrated to be safe without any significant side effects (NCT01212341). Allogeneic NK cell therapy is currently applied to patients with advanced hepatocellular carcinoma after curative resection (NCT02008929). In this clinical trial, ex vivo-expanded allogeneic NK cells were administered without combination with other therapeutic modalities to investigate the isolated effect of infused allogeneic NK cells.

Taken together, the clinical studies mentioned above demonstrated that the infusion of allogeneic NK cells after ex vivo expansion is largely safe and some responses appear encouraging.

\section{Optimized Selection of Donors}

\section{Lessons from Allogeneic HSCT}

In T cell-depleted HSCT, donor NK cells are the major effector cells responsible for controlling residual cancer cells (19), and it has been shown that the KIR genotype of donors influences the outcome of HSCT (30). From the experience of allogeneic 
HSCT, we can learn how allogeneic NK cell donors are selected to maximize the antitumor activity of infused allogeneic NK cells.

There are two distinct types of KIR haplotypes: group A and group B. The KIR group B haplotype has more activating receptors than the KIR group A haplotype (31). According to the KIR genotype, all individuals can be divided into the A/A genotype (homozygous for $\mathrm{A}$ haplotypes) or the $\mathrm{B} / \mathrm{x}$ genotype (having 1 or $2 \mathrm{~B}$ haplotypes). There have been reports that the donor KIR genotype influences outcomes of unrelated HSCT for acute hematological malignancies and that the $\mathrm{B} / \mathrm{x}$ genotype confers significant survival benefit to patients $(22,32,33)$. B/x donors are further differentiated on whether their $\mathrm{B}$ haplotype genes are in the centromeric or/and telomeric part. On the basis of this information, the KIR B-content score can be calculated from 0 to $4(30,34)$. High donor KIR B-content scores have been associated with a significantly reduced relapse in children after haploidentical HSCT for acute lymphocytic leukemia (ALL) (35), and donors with two or more B-content scores showed superior survival after unrelated HSCT for AML (27).

Incompatibility between KIRs of donors and HLAs of recipients is also an important factor. Considering that each KIR binds to specific HLA allotypes as an inhibitory ligand (e.g., KIR2DL1 to group 2 HLA-C, KIR2DL2/3 to group 1 HLA-C, and KIR3DL1 to HLA-Bw4), a recipient may lack specific HLA allotypes that inhibit donor NK cells. In this case, higher antitumor activity of donor NK cells is expected. Indeed, antitumor activity of donor NK cells is significantly improved when KIRs and HLAs are incompatible between donor and recipient $(19,24,36)$.

In addition to the KIR genotype and incompatibility, actual expression of KIRs on NK cells needs to be considered for the best antitumor activity of allogeneic NK cells because the expression of KIRs occurs in stochastic combination (37). Antitumor activity is likely to be mediated by single- $\mathrm{KIR}^{+}$allogeneic NK cells not encountering any inhibitory signal from HLA molecules on recipient cells (38). Although NK cells are the first lymphoid population to recover after allogeneic HSCT (21), reconstitution of mature NK receptor repertoires requires at least 3 months (39). Importantly, during this period, donor-derived single-KIR ${ }^{+} \mathrm{NK}$ cells are not fully functional (38). In this aspect, infusion of single$\mathrm{KIR}^{+}$mature NK cells selected for KIR-HLA mismatches might lead to better clinical outcomes. Currently, multicolor flow cytometry enables the examination of KIR expression in the NK cell population. The approach to generate GMP-grade single-KIR ${ }^{+}$ NK cells (40) will allow customized allogeneic NK cell therapy.

\section{Sources of Allogeneic NK Cells}

To permit therapeutic use of allogeneic NK cells in clinical settings, a sufficient number of highly enriched NK cells must be obtained. The sources for allogeneic NK cells include peripheral blood mononuclear cells (PBMCs) collected by leukapheresis from healthy donors and umbilical cord blood (UCB).

Peripheral blood mononuclear cells collected by leukapheresis are generally utilized as a source of allogeneic NK cells. Various methods to obtain ex vivo-expanded, activated, and $\mathrm{CD}^{+}$ T cell-depleted NK cells have been well established in clinical scales and grades (41). Although those NK cells showed potent antitumor efficacy in vitro and in vivo, clinical outcomes were insufficient. The clinical results might be influenced by several factors including malignancy types and pre-conditioning treatment. As described above, the therapeutic efficacy of allogeneic NK cell therapy can be potentiated by optimal selection of NK cell donors in a non-HSCT setting. Since NK cells from haploidentical donors had been used in allogeneic HSCT settings, allogeneic NK cells were mostly obtained from haploidentical donors even in a nonHSCT setting. Recently, ex vivo-expanded, allogeneic NK cells from unrelated, random donors were successfully administered to patients with malignant lymphoma or advanced solid tumors in a phase 1 trial (NCT01212341) that has proceeded to a phase 2 trial of patients with hepatocellular carcinoma (NCT02008929). This strategy, which used unrelated NK donors, allowed free selection of the best donor in terms of donor KIR-recipient HLA incompatibility without limitation of small pools of related donors. Furthermore, the use of allogeneic NK cells from non-HLA-related healthy donors allows preparation of expanded, cryopreserved NK cells for instant administration without delay for ex vivo expansion.

Umbilical cord blood is another promising source of allogeneic NK cells. However, cytokine-based differentiation of CD34 ${ }^{+}$ hematopoietic stem and progenitor cells to NK cells needs to be carried out to obtain large numbers of functional NK cells from UCB (42). This process requires high-dose cytokine cocktails and delicate culture regimens that may result in low-cost effectiveness. Recently, an NK cell expansion method from UCB using artificial antigen presenting feeder cells was reported. NK cells expanded by this method showed in vitro cytotoxicity against various myeloma targets and in vivo antitumor activity in a mouse model of myeloma (43).

\section{Future Directions}

\section{Genetic Modification}

Genetic modification is a promising option for redirecting the function of various types of immune cells (44). Much work has been performed, particularly on genetically redirecting $\mathrm{T}$ cells against a range of tumor antigens. For example, $\mathrm{T}$ cells expressing chimeric antigen receptors (CARs) targeting CD19 antigens have been developed to treat B-cell-derived malignancy, and clinical trials are currently ongoing (45-47). The successful experience with CAR-expressing $\mathrm{T}$ cells in the treatment of hematological malignancies has prompted the development of CAR-expressing NK cells. NK cells are attractive for CAR expression because they have cytotoxic function and, unlike T cells, allogeneic NK cells do not cause GVHD.

As summarized in Table 2, two clinical trials are investigating the use of CAR-expressing allogeneic NK cells. The aim of both studies is to assess the safety, feasibility, and efficacy of expanded, activated, and CD19-redirected haploidentical NK cells in ALL patients who have persistent disease after intensive chemotherapy or HSCT (NCT00995137, NCT01974479). Further, other tumor antigens, such as CS1, CEA, CD138, and CD33, are targeted by CARs expressed by NK cells, although NK-92, YT, or NKL cell lines were used (48-51).

Genetic modification is also performed to express cytokine transgenes in NK cells. NK cell function could be enhanced by 
TABLE 2 | Genetically modified, expanded allogeneic NK cells.

\begin{tabular}{|c|c|c|c|c|c|}
\hline Modification & $\begin{array}{l}\text { Genes } \\
\text { transferred }\end{array}$ & NK cells & Application & Status & Reference/ClinicalTrials.gov Identifier \\
\hline \multirow[t]{5}{*}{ Target specificity } & CD19 & $\begin{array}{l}\text { Haploidentical, expanded } \\
\text { NK cells }\end{array}$ & ALL & Phase 1 & $\begin{array}{l}\text { St. Jude Children's Research Hospital } \\
\text { (NCT00995137) }\end{array}$ \\
\hline & CD19 & $\begin{array}{l}\text { Haploidentical, expanded } \\
\text { NK cells }\end{array}$ & ALL & Phase 2 & $\begin{array}{l}\text { National University Health System, } \\
\text { Singapore (NCT01974479) }\end{array}$ \\
\hline & CD19 & Expanded NK cells & B-ALL & Preclinical & Cho et al. (52) \\
\hline & CD20 & Expanded NK cells & $\mathrm{CD} 2 \mathrm{O}^{+} \mathrm{B}-\mathrm{NHL}$ & Preclinical & Chu et al. (53) \\
\hline & GD2 & Expanded NK cells & Neuroblastoma & Preclinical & Esser et al. (54) \\
\hline \multirow[t]{2}{*}{ NK cell function } & NKG2D & Expanded NK cells & Various tumor targets (B-ALL etc.) & Preclinical & Chang et al. (55) \\
\hline & IL-12 & IL-2-activated NK cells & B16 lung tumor & Preclinical & Goding et al. (56) \\
\hline
\end{tabular}

ALL, acute lymphocytic leukemia; B-NHL, B-cell non-Hodgkin lymphoma; B-ALL, B-cell acute lymphoblastic leukemia.

expression of cytokines, such as IL-2 $(57,58)$, IL-12 $(56,59)$, and IL-15 (60-62). Cytokine expression enhances the activation of NK cells, survival and proliferation of NK cells, and accumulation of NK cells in tumor tissues. To improve the efficacy of NK cell therapy, genetic modification of NK cells is explored to express activating receptors, such as NKG2D (55).

\section{Therapeutic Regimens}

In allogeneic NK cell therapy, optimal therapeutic regimens for clinical applications should be considered because adoptively transferred NK cells not only target tumor cells but also interact with the immunological environment. To potentiate the therapeutic efficacy of allogeneic NK cells, proper strategies, including pre-conditioning or combination therapy, could be applied (34).

Upregulation of NKG2D ligands by spironolactone (63) or histone deacetylase inhibitors $(64,65)$ and upregulation of TRAIL-R2 by doxorubicin (66) result in enhanced antitumor efficacy of NK cells. Proteasome inhibitors also sensitize tumor cells to NK cellmediated killing via TRAIL and FasL pathways. In addition, c-kit tyrosine kinase inhibitor (67) and JAK inhibitors (68) increase the susceptibility of tumor cells to NK cytotoxicity and enhance antitumor responses by increased IFN- $\gamma$ production from NK cells. However, protein kinase inhibitors should be used cautiously because some protein kinase inhibitors, such as sorafenib, inhibit the effector function of NK cells (69).

Immunomodulatory drugs can augment NK cell function. Lenalidomide enhances rituximab-induced killing of nonHodgkin's lymphoma and B-cell chronic lymphocytic leukemia through NK cell and monocyte-mediated ADCC mechanisms (70). Combination therapy using IL-2 and anti-CD25 shows

\section{References}

1. Stewart BW, Wild CP. World Cancer Report 2014. Lyon: IARC Press, International Agency for Research on Cancer (2014).

2. Vanneman M, Dranoff G. Combining immunotherapy and targeted therapies in cancer treatment. Nat Rev Cancer (2012) 12(4):237-51. doi:10.1038/nrc3237

3. Terme M, Ullrich E, Delahaye NF, Chaput N, Zitvogel L. Natural killer celldirected therapies: moving from unexpected results to successful strategies. Nat Immunol (2008) 9(5):486-94. doi:10.1038/ni1580

4. Sutlu T, Alici E. Natural killer cell-based immunotherapy in cancer: current insights and future prospects. J Intern Med (2009) 266(2):154-81. doi:10.1111/ j.1365-2796.2009.02121.x anti-leukemic effects by depletion of regulatory $\mathrm{T}$ cells in addition to activation and expansion of NK cells (71). Alloferon, an immunomodulatory peptide, enhances the expression of NKactivating receptor $2 \mathrm{~B} 4$ and granule exocytosis from $\mathrm{NK}$ cells against cancer cells (72).

Therapeutic antibodies can be combined with allogeneic NK cell therapy (73). Antibodies against tumor antigens (e.g., CD20 and CS1) can induce ADCC of NK cells $(74,75)$. Antibodies to activating NK receptors (e.g., 4-1BB, GITR, NKG2D, DNAM-1, and NCRs) can enhance NK activation (74, 76-79). In addition, inhibitory receptors (e.g., KIR2DL, PD-1, PD-L1, and NKG2A) can be blocked by antibodies (80-85). Bispecific and trispecific killer cell engagers directly activate NK cells through CD16 signaling and thus, induce cytotoxicity and cytokine production against tumor targets $(86,87)$.

\section{Conclusion}

Antitumor activity of allogeneic NK cells was first observed in a setting of HLA-haploidentical HSCT. Allogeneic NK cell therapy was tried mostly using HLA-haploidentical NK cells with or without allogeneic HSCT and, recently, allogeneic NK cells from unrelated, random donors have been used in a non-HSCT setting. The efficacy of allogeneic NK cell therapy can be enhanced by optimal donor selection in terms of the KIR genotype of donors and donor KIR-recipient MHC incompatibility. Furthermore, efficacy can be increased by genetic modification of NK cells and optimized therapeutic regimens. In the future, allogeneic NK cell therapy can be an effective therapeutic modality for cancer treatment.

5. Martinet L, Smyth MJ. Balancing natural killer cell activation through paired receptors. Nat Rev Immunol (2015) 15(4):243-54. doi:10.1038/nri3799

6. Ljunggren H-G, Malmberg K-J. Prospects for the use of NK cells in immunotherapy of human cancer. Nat Rev Immunol (2007) 7(5):329-39. doi:10. 1038/nri2073

7. Alderson KL, Sondel PM. Clinical cancer therapy by NK cells via antibodydependent cell-mediated cytotoxicity. J Biomed Biotechnol (2011) 2011:379123. doi:10.1155/2011/379123

8. Vivier E, Tomasello E, Baratin M, Walzer T, Ugolini S. Functions of natural killer cells. Nat Immunol (2008) 9(5):503-10. doi:10.1038/ni1582

9. Lanier LL. NK cell recognition. Annu Rev Immunol (2005) 23:225-74. doi:10 1146/annurev.immunol.23.021704.115526 
10. Long EO, Kim HS, Liu D, Peterson ME, Rajagopalan S. Controlling NK cell responses: integration of signals for activation and inhibition. Annu Rev Immunol (2013) 31:227-58. doi:10.1146/annurev-immunol-020711-075005

11. Moretta A, Bottino C, Vitale M, Pende D, Cantoni C, Mingari MC, et al. Activating receptors and coreceptors involved in human natural killer cellmediated cytolysis. Annu Rev Immunol (2001) 19(1):197-223. doi:10.1146/ annurev.immunol.19.1.197

12. Long EO. Regulation of immune responses through inhibitory receptors. Annu Rev Immunol (1999) 17(1):875-904. doi:10.1146/annurev.immunol.17.1.875

13. Braud VM, Allan DS, O'Callaghan CA, Söderström K, D’Andrea A, Ogg GS, et al. HLA-E binds to natural killer cell receptors CD94/NKG2A, B and C. Nature (1998) 391(6669):795-9. doi:10.1038/35869

14. Marincola FM, Jaffee EM, Hicklin DJ, Ferrone S. Escape of human solid tumors from T-cell recognition: molecular mechanisms and functional significance. Adv Immunol (2000) 74:181-273. doi:10.1016/S0065-2776(08)60911-6

15. Platonova S, Cherfils-Vicini J, Damotte D, Crozet L, Vieillard V, Validire P, et al. Profound coordinated alterations of intratumoral NK cell phenotype and function in lung carcinoma. Cancer Res (2011) 71(16):5412-22. doi:10.1158/ 0008-5472.CAN-10-4179

16. Thielens A, Vivier E, Romagné F. NK cell MHC class I specific receptors (KIR): from biology to clinical intervention. Curr Opin Immunol (2012) 24(2):239-45. doi:10.1016/j.coi.2012.01.001

17. Shilling HG, Young N, Guethlein LA, Cheng NW, Gardiner CM, Tyan D, et al. Genetic control of human NK cell repertoire. J Immunol (2002) 169(1):239-47. doi:10.4049/jimmunol.169.1.239

18. Korngold R, Sprent J. Lethal graft-versus-host disease after bone marrow transplantation across minor histocompatibility barriers in mice. Prevention by removing mature T cells from marrow. J Exp Med (1978) 148(6):1687-98. doi:10.1084/jem.148.6.1687

19. Ruggeri L, Capanni M, Urbani E, Perruccio K, Shlomchik WD, Tosti A, et al. Effectiveness of donor natural killer cell alloreactivity in mismatched hematopoietic transplants. Science (2002) 295(5562):2097-100. doi:10.1126/ science. 1068440

20. Venstrom JM, Pittari G, Gooley TA, Chewning JH, Spellman S, Haagenson M, et al. HLA-C-dependent prevention of leukemia relapse by donor activating KIR2DS1. N Engl J Med (2012) 367(9):805-16. doi:10.1056/NEJMoa1200503

21. Wu CJ, Ritz J. Induction of tumor immunity following allogeneic stem cell transplantation. Adv Immunol (2006) 90:133-73. doi:10.1016/S0065-2776(06) 90004-2

22. Impola U, Turpeinen H, Alakulppi N, Linjama T, Volin L, Niittyvuopio R, et al. Donor haplotype B of NK KIR receptor reduces the relapse risk in HLAidentical sibling hematopoietic stem cell transplantation of AML patients. Front Immunol (2014) 5:405. doi:10.3389/fimmu.2014.00405

23. Romee R, Leong JW, Fehniger TA. Utilizing cytokines to function-enable human NK cells for the immunotherapy of cancer. Scientifica (2014) 2014:205796. doi:10.1155/2014/205796

24. Ruggeri L, Mancusi A, Capanni M, Urbani E, Carotti A, Aloisi T, et al. Donor natural killer cell allorecognition of missing self in haploidentical hematopoietic transplantation for acute myeloid leukemia: challenging its predictive value. Blood (2007) 110(1):433-40. doi:10.1182/blood-2006-07-038687

25. Rubnitz JE, Inaba H, Ribeiro RC, Pounds S, Rooney B, Bell T, et al. NKAML: a pilot study to determine the safety and feasibility of haploidentical natural killer cell transplantation in childhood acute myeloid leukemia. J Clin Oncol (2010) 28(6):955-9. doi:10.1200/JCO.2009.24.4590

26. Iliopoulou EG, Kountourakis P, Karamouzis MV, Doufexis D, Ardavanis A, Baxevanis $\mathrm{CN}$, et al. A phase I trial of adoptive transfer of allogeneic natural killer cells in patients with advanced non-small cell lung cancer. Cancer Immunol Immunother (2010) 59(12):1781-9. doi:10.1007/s00262-010-0904-3

27. Miller JS, Soignier Y, Panoskaltsis-Mortari A, McNearney SA, Yun GH, Fautsch SK, et al. Successful adoptive transfer and in vivo expansion of human haploidentical NK cells in patients with cancer. Blood (2005) 105(8):3051-7. doi:10. 1182/blood-2004-07-2974

28. Re F, Staudacher C, Zamai L, Vecchio V, Bregni M. Killer cell Ig-like receptors ligand-mismatched, alloreactive natural killer cells lyse primary solid tumors. Cancer (2006) 107(3):640-8. doi:10.1002/cncr.22002

29. Geller MA, Cooley S, Judson PL, Ghebre R, Carson LF, Argenta PA, et al. A phase II study of allogeneic natural killer cell therapy to treat patients with recurrent ovarian and breast cancer. Cytotherapy (2011) 13(1):98-107. doi:10. 3109/14653249.2010.515582
30. Cooley S, Weisdorf DJ, Guethlein LA, Klein JP, Wang T, Le CT, et al. Donor selection for natural killer cell receptor genes leads to superior survival after unrelated transplantation for acute myelogenous leukemia. Blood (2010) 116(14):2411-9. doi:10.1182/blood-2010-05-283051

31. Uhrberg M, Valiante NM, Shum BP, Shilling HG, Lienert-Weidenbach K, Corliss B, et al. Human diversity in killer cell inhibitory receptor genes. Immunity (1997) 7(6):753-63. doi:10.1016/S1074-7613(00)80394-5

32. Cooley S, Trachtenberg E, Bergemann TL, Saeteurn K, Klein J, Le CT, et al. Donors with group B KIR haplotypes improve relapse-free survival after unrelated hematopoietic cell transplantation for acute myelogenous leukemia. Blood (2009) 113(3):726-32. doi:10.1182/blood-2008-07-171926

33. Symons HJ, Leffell MS, Rossiter ND, Zahurak M, Jones RJ, Fuchs EJ. Improved survival with inhibitory killer immunoglobulin receptor (KIR) gene mismatches and KIR haplotype B donors after nonmyeloablative, HLA-haploidentical bone marrow transplantation. Biol Blood Marrow Transplant (2010) 16(4):533-42. doi:10.1016/j.bbmt.2009.11.022

34. Leung W. Infusions of allogeneic natural killer cells as cancer therapy. Clin Cancer Res (2014) 20(13):3390-400. doi:10.1158/1078-0432.CCR-13-1766

35. Oevermann L, Michaelis SU, Mezger M, Lang P, Toporski J, Bertaina A, et al. KIR B haplotype donors confer a reduced risk for relapse after haploidentical transplantation in children with ALL. Blood (2014) 124(17):2744. doi:10.1182/ blood-2014-03-565069

36. Ruggeri L, Mancusi A, Capanni M, Martelli MF, Velardi A. Exploitation of alloreactive NK cells in adoptive immunotherapy of cancer. Curr Opin Immunol (2005) 17(2):211-7. doi:10.1016/j.coi.2005.01.007

37. Leung W, Iyengar R, Triplett B, Turner V, Behm FG, Holladay MS, et al. Comparison of killer Ig-like receptor genotyping and phenotyping for selection of allogeneic blood stem cell donors. J Immunol (2005) 174(10):6540-5. doi:10. 4049/jimmunol.174.10.6540

38. Vago L, Forno B, Sormani MP, Crocchiolo R, Zino E, Di Terlizzi S, et al. Temporal, quantitative, and functional characteristics of single-KIR-positive alloreactive natural killer cell recovery account for impaired graft-versusleukemia activity after haploidentical hematopoietic stem cell transplantation. Blood (2008) 112(8):3488-99. doi:10.1182/blood-2007-07-103325

39. Tanaka J, Mori A, Ohta S, Yamamoto Y, Kobayashi S, Hashino S, et al. Expression of HLA-C-specific natural killer cell receptors (CD158a and CD158b) on peripheral blood mononuclear cells after allogeneic bone marrow transplantation. Br J Haematol (2000) 108(4):778-83. doi:10.1046/j.1365-2141. 2000.01938.x

40. Siegler U, Meyer-Monard S, Jörger S, Stern M, Tichelli A, Gratwohl A, et al. Good manufacturing practice-compliant cell sorting and large-scale expansion of single KIR-positive alloreactive human natural killer cells for multiple infusions to leukemia patients. Cytotherapy (2010) 12(6):750-63. doi:10.3109/ 14653241003786155

41. Koepsell SA, Miller JS, McKenna DH Jr. Natural killer cells: a review of manufacturing and clinical utility. Transfusion (2013) 53(2):404-10. doi:10.1111/j. 1537-2995.2012.03724.x

42. Spanholtz J, Preijers F, Tordoir M, Trilsbeek C, Paardekooper J, De Witte T, et al. Clinical-grade generation of active NK cells from cord blood hematopoietic progenitor cells for immunotherapy using a closed-system culture process. PLoS One (2011) 6(6):e20740. doi:10.1371/journal.pone.0020740

43. Shah N, Martin-Antonio B, Yang H, Ku S, Lee DA, Cooper LJ, et al. Antigen presenting cell-mediated expansion of human umbilical cord blood yields logscale expansion of natural killer cells with anti-myeloma activity. PLoS One (2013) 8(10):e76781. doi:10.1371/journal.pone.0076781

44. Pegram HJ, Kershaw MH, Darcy PK. Genetic modification of natural killer cells for adoptive cellular immunotherapy. Immunotherapy (2009) 1(4):623-30. doi:10.2217/imt.09.36

45. Grupp SA, Kalos M, Barrett D, Aplenc R, Porter DL, Rheingold SR, et al. Chimeric antigen receptor-modified $\mathrm{T}$ cells for acute lymphoid leukemia. $\mathrm{N}$ Engl J Med (2013) 368(16):1509-18. doi:10.1056/NEJMoa1215134

46. Maude SL, Frey N, Shaw PA, Aplenc R, Barrett DM, Bunin NJ, et al. Chimeric antigen receptor $\mathrm{T}$ cells for sustained remissions in leukemia. $N$ Engl J Med (2014) 371(16):1507-17. doi:10.1056/NEJMoa1407222

47. Lee DW, Kochenderfer JN, Stetler-Stevenson M, Cui YK, Delbrook C, Feldman SA, et al. T cells expressing CD19 chimeric antigen receptors for acute lymphoblastic leukaemia in children and young adults: a phase 1 doseescalation trial. Lancet (2015) 385(9967):517-28. doi:10.1016/S0140-6736(14) 61403-3 
48. Chu J, Deng Y, Benson D, He S, Hughes T, Zhang J, et al. CS1-specific chimeric antigen receptor (CAR)-engineered natural killer cells enhance in vitro and in vivo antitumor activity against human multiple myeloma. Leukemia (2014) 28(4):917-27. doi:10.1038/leu.2013.279

49. Schirrmann T, Pecher G. Human natural killer cell line modified with a chimeric immunoglobulin T-cell receptor gene leads to tumor growth inhibition in vivo. Cancer Gene Ther (2002) 9(4):390-8. doi:10.1038/sj.cgt. 7700453

50. Jiang H, Zhang W, Shang P, Zhang H, Fu W, Ye F, et al. Transfection of chimeric anti-CD138 gene enhances natural killer cell activation and killing of multiple myeloma cells. Mol Oncol (2014) 8(2):297-310. doi:10.1016/j.molonc. 2013.12.001

51. Schirrmann T, Pecher G. Specific targeting of CD33+ leukemia cells by a natural killer cell line modified with a chimeric receptor. Leuk Res (2005) 29(3):301-6. doi:10.1016/j.leukres.2004.07.005

52. Cho F-N, Chang T-H, Shu C-W, Ko M-C, Liao S-K, Wu K-H, et al. Enhanced cytotoxicity of natural killer cells following the acquisition of chimeric antigen receptors through trogocytosis. PLoS One (2014) 9(10):e109352. doi:10.1371/ journal.pone.0109352

53. Chu Y, Hochberg J, Yahr A, Ayello J, van de Ven C, Barth MJ, et al. Targeting CD20+ aggressive B-cell non-hodgkin lymphoma by anti-CD20 CAR mRNA modified expanded natural killer cells in vitro and in NSG mice. Cancer Immunol Res (2014) 3(4):333-44. doi:10.1158/2326-6066.CIR-14-0114

54. Esser R, Müller T, Stefes D, Kloess S, Seidel D, Gillies SD, et al. NK cells engineered to express a GD2-specific antigen receptor display built-in ADCClike activity against tumour cells of neuroectodermal origin. J Cell $\mathrm{Mol} \mathrm{Med}$ (2012) 16(3):569-81. doi:10.1111/j.1582-4934.2011.01343.x

55. Chang Y-H, Connolly J, Shimasaki N, Mimura K, Kono K, Campana D. A chimeric receptor with NKG2D specificity enhances natural killer cell activation and killing of tumor cells. Cancer Res (2013) 73(6):1777-86. doi:10.1158/ 0008-5472.CAN-12-3558

56. Goding SR, Yang Q, Knudsen KB, Potter DM, Basse PH. Cytokine gene therapy using adenovirally transduced, tumor-seeking activated natural killer cells. Hum Gene Ther (2007) 18(8):701-11. doi:10.1089/hum.2007.052

57. Nagashima S, Mailliard R, Kashii Y, Reichert TE, Herberman RB, Robbins P, et al. Stable transduction of the interleukin-2 gene into human natural killer cell lines and their phenotypic and functional characterization in vitro and in vivo. Blood (1998) 91(10):3850-61.

58. Vujanovic NL, Yasumura S, Hirabayashi H, Lin W, Watkins S, Herberman RB, et al. Antitumor activities of subsets of human IL-2-activated natural killer cells in solid tissues. J Immunol (1995) 154(1):281-9.

59. Goding S, Yang Q, Mi Z, Robbins P, Basse P. Targeting of products of genes to tumor sites using adoptively transferred A-NK and T-LAK cells. Cancer Gene Ther (2007) 14(5):441-50. doi:10.1038/sj.cgt.7701019

60. Cooper MA, Bush JE, Fehniger TA, VanDeusen JB, Waite RE, Liu Y, et al. In vivo evidence for a dependence on interleukin 15 for survival of natural killer cells. Blood (2002) 100(10):3633-8. doi:10.1182/blood-2001-12-0293

61. Ranson T, Vosshenrich CA, Corcuff E, Richard O, Müller W, Di Santo JP. IL15 is an essential mediator of peripheral NK-cell homeostasis. Blood (2003) 101(12):4887-93. doi:10.1182/blood-2002-11-3392

62. Jiang W, Zhang J, Tian Z. Functional characterization of interleukin-15 gene transduction into the human natural killer cell line NKL. Cytotherapy (2008) 10(3):265-74. doi:10.1080/14653240801965156

63. Leung W-H, Vong QP, Lin W, Janke L, Chen T, Leung W. Modulation of NKG2D ligand expression and metastasis in tumors by spironolactone via RXR $\gamma$ activation. J Exp Med (2013) 210(12):2675-92. doi:10.1084/jem. 20122292

64. Skov S, Pedersen MT, Andresen L, Straten PT, Woetmann A, Ødum N. Cancer cells become susceptible to natural killer cell killing after exposure to histone deacetylase inhibitors due to glycogen synthase kinase-3-dependent expression of MHC class I-related chain A and B. Cancer Res (2005) 65(23):11136-45. doi:10.1158/0008-5472.CAN-05-0599

65. Diermayr S, Himmelreich H, Durovic B, Mathys-Schneeberger A, Siegler U, Langenkamp U, et al. NKG2D ligand expression in AML increases in response to HDAC inhibitor valproic acid and contributes to allorecognition by NK-cell lines with single KIR-HLA class I specificities. Blood (2008) 111(3):1428-36. doi:10.1182/blood-2007-07-101311

66. Wennerberg E, Sarhan D, Carlsten M, Kaminskyy VO, D’Arcy P, Zhivotovsky B, et al. Doxorubicin sensitizes human tumor cells to NK cell- and
T-cell-mediated killing by augmented TRAIL receptor signaling. Int J Cancer (2013) 133(7):1643-52. doi:10.1002/ijc.28163

67. Borg C, Terme M, Taïeb J, Ménard C, Flament C, Robert C, et al. Novel mode of action of c-kit tyrosine kinase inhibitors leading to NK cell-dependent antitumor effects. J Clin Invest (2004) 114(3):379. doi:10.1172/JCI200421102

68. Bellucci R, Nguyen H-N, Martin A, Heinrichs S, Schinzel AC, Hahn WC, et al. Tyrosine kinase pathways modulate tumor susceptibility to natural killer cells. J Clin Invest (2012) 122(7):2369. doi:10.1172/JCI58457

69. Krusch M, Salih J, Schlicke M, Baessler T, Kampa KM, Mayer F, et al. The kinase inhibitors sunitinib and sorafenib differentially affect NK cell antitumor reactivity in vitro. J Immunol (2009) 183(12):8286-94. doi:10.4049/jimmunol. 0902404

70. Wu L, Adams M, Carter T, Chen R, Muller G, Stirling D, et al. Lenalidomide enhances natural killer cell and monocyte-mediated antibody-dependent cellular cytotoxicity of rituximab-treated CD20+ tumor cells. Clin Cancer Res (2008) 14(14):4650-7. doi:10.1158/1078-0432.CCR-07-4405

71. Hallett WH, Ames E, Álvarez M, Barao I, Taylor PA, Blazar BR, et al. Combination therapy using IL-2 and anti-CD25 results in augmented natural killer cell-mediated antitumor responses. Biol Blood Marrow Transplant (2008) 14(10):1088-99. doi:10.1016/j.bbmt.2008.08.001

72. Bae S, Oh K, Kim H, Kim Y, Kim H-R, Hwang Y-I, et al. The effect of alloferon on the enhancement of NK cell cytotoxicity against cancer via the up-regulation of perforin/granzyme B secretion. Immunobiology (2013) 218(8):1026-33. doi:10. 1016/j.imbio.2012.12.002

73. James AM, Cohen AD, Campbell KS. Combination immune therapies to enhance anti-tumor responses by NK cells. Front Immunol (2013) 4:481. doi:10. 3389/fimmu.2013.00481

74. Moreau P, editor. The future of therapy for relapsed/refractory multiple myeloma: emerging agents and novel treatment strategies. Semin Hematol (2012) 49(Suppl 1):S3346. doi:10.1053/j.seminhematol.2012.05.004

75. Benson DM, Byrd JC. CS1-directed monoclonal antibody therapy for multiple myeloma. J Clin Oncol (2012) 30(16):2013-5. doi:10.1200/JCO.2011.40.4061

76. Kohrt HE, Houot R, Weiskopf K, Goldstein MJ, Scheeren F, Czerwinski D, et al. Stimulation of natural killer cells with a CD137-specific antibody enhances trastuzumab efficacy in xenotransplant models of breast cancer. J Clin Invest (2012) 122(3):1066-75. doi:10.1172/JCI61226

77. Buechele C, Baessler T, Schmiedel BJ, Schumacher CE, Grosse-Hovest L, Rittig $\mathrm{K}$, et al. 4-1BB ligand modulates direct and rituximab-induced NK-cell reactivity in chronic lymphocytic leukemia. Eur J Immunol (2012) 42(3):737-48. doi:10.1002/eji.201141920

78. Buechele C, Baessler T, Wirths S, Schmohl J, Schmiedel B, Salih H. Glucocorticoid-induced TNFR-related protein (GITR) ligand modulates cytokine release and NK cell reactivity in chronic lymphocytic leukemia (CLL). Leukemia (2012) 26(5):991-1000. doi:10.1038/leu.2011.313

79. Schmiedel BJ, Werner A, Steinbacher J, Nuebling T, Buechele C, Grosse-Hovest $\mathrm{L}$, et al. Generation and preclinical characterization of a Fc-optimized GITR-Ig fusion protein for induction of NK cell reactivity against leukemia. Mol Ther (2013) 21(4):877-86. doi:10.1038/mt.2013.11

80. Vey N, Bourhis J-H, Boissel N, Bordessoule D, Prebet T, Charbonnier A, et al. A phase 1 trial of the anti-inhibitory KIR mAb IPH2101 for AML in complete remission. Blood (2012) 120(22):4317-23. doi:10.1182/blood-2012-06-437558

81. Benson DM Jr, Hofmeister CC, Padmanabhan S, Suvannasankha A, Jagannath $\mathrm{S}$, Abonour R, et al. A phase 1 trial of the anti-KIR antibody IPH2101 in patients with relapsed/refractory multiple myeloma. Blood (2012) 120(22):4324-33. doi:10.1182/blood-2012-06-438028

82. Kohrt HE, Thielens A, Marabelle A, Sagiv-Barfi I, Sola C, Chanuc F, et al. AntiKIR antibody enhancement of anti-lymphoma activity of natural killer cells as monotherapy and in combination with anti-CD20 antibodies. Blood (2014) 123(5):678-86. doi:10.1182/blood-2013-08-519199

83. Benson DM Jr, Bakan CE, Mishra A, Hofmeister CC, Efebera Y, Becknell B, et al. The PD-1/PD-L1 axis modulates the natural killer cell versus multiple myeloma effect: a therapeutic target for CT-011, a novel monoclonal anti-PD-1 antibody. Blood (2010) 116(13):2286-94. doi:10.1182/blood-2010-02-271874

84. Lipson EJ, Sharfman WH, Drake CG, Wollner I, Taube JM, Anders RA, et al. Durable cancer regression off-treatment and effective reinduction therapy with an anti-PD-1 antibody. Clin Cancer Res (2013) 19(2):462-8. doi:10.1158/ 1078-0432.CCR-12-2625

85. Binyamin L, Alpaugh RK, Hughes TL, Lutz CT, Campbell KS, Weiner LM. Blocking NK cell inhibitory self-recognition promotes antibody-dependent 
cellular cytotoxicity in a model of anti-lymphoma therapy. J Immunol (2008) 180(9):6392-401. doi:10.4049/jimmunol.180.9.6392

86. Gleason MK, Verneris MR, Todhunter DA, Zhang B, McCullar V, Zhou SX, et al. Bispecific and trispecific killer cell engagers directly activate human NK cells through CD16 signaling and induce cytotoxicity and cytokine production. Mol Cancer Ther (2012) 11(12):2674-84. doi:10.1158/1535-7163. MCT-12-0692

87. Gleason MK, Ross JA, Warlick ED, Lund TC, Verneris MR, Wiernik A, et al. $\mathrm{CD} 16 \mathrm{xCD} 33$ bispecific killer cell engager (BiKE) activates NK cells against primary MDS and MDSC CD33+ targets. Blood (2014) 123(19):3016-26. doi:10. 1182/blood-2013-10-533398
Conflict of Interest Statement: Yu Kyeong Hwang is a current employee of GreenCross LabCell. The other co-authors declare that the research was conducted in the absence of any commercial or financial relationships that could be construed as a potential conflict of interest.

Copyright $\odot 2015$ Lim, Jung, Hwang and Shin. This is an open-access article distributed under the terms of the Creative Commons Attribution License (CC BY). The use, distribution or reproduction in other forums is permitted, provided the original author(s) or licensor are credited and that the original publication in this journal is cited, in accordance with accepted academic practice. No use, distribution or reproduction is permitted which does not comply with these terms. 